\title{
Book-Learning and Learning Books
}

Summerfield Baldwin III is assistant professor of history at Flora Stone Mather College, Cleveland.

$\mathrm{W}$

HEN I first visited Cleveland, a number of years ago, I was anxious to meet a professor at Western Reserve University, now a valued colleague, with whom I had been in correspondence. I called up his home, and was informed that I could find him at the library. "The university library?" I asked. "No. The public library, downtown. It's just around the corner from your hotel." The suggestion that I could find my man at a public library seemed rather like being told that I could find a needle in a haystack, especially since I did not even know what he looked like. But even worse: I could not imagine what such a learned individual as I knew the professor to be could find to interest him in a public library. My experience with public libraries in other cities had taught me that their collections were formed with almost everybody in mind except scholars.

However, I went to the public library, and boldly approached the information desk with my preposterous inquiry: "Is Professor So-and-so, of Western Reserve University, in the library?" The lady in charge did not even raise her eyebrows. "Yes, I think so," she replied. "He came in about an hour ago, and you will probably find him in the history room on the second floor." You could have knocked me over with a feather, but I remembered to say thank you, and proceeded to the history room, again directing my inquiry (with rather greater confidence) to one of the librarians. "Yes," she said, "that's Professor So-and-so, in the overcoat, over there, bending over one of the tables." Like Stanley, in darkest Africa, I approached and offered the well known formula: "Professor So-and-so I presume?" It was, and I got an invitation to dinner, on the spot.

I did not leave the public library, however, until my new friend had done everything possible to solve for me the other problem which had disturbed me when I first set out on my quest: What could a scholar find to interest him in a public library? He showed me, on the miraculously open shelves of the history room, the impressive collections in English history: the Rolls series, complete, the multivolumed Calendars published by the Record Commission, the complete files of historical journals. $\mathrm{He}$ explained to me something of the program followed by Mather College freshmen who, every year, prepared a paper on the events of one month in the reign of Queen Elizabeth, based on original documents, and pointed out to me a number of his students sitting at different tables about the room, taking notes from various volumes of the Calendar of State Papers. "We have a good 
deal of this material," he told me, "at the college library, too, but we try to make it a point to collaborate with the public library, and avoid as much duplication of these expensive sets as we can. Then, too, it's a good thing for the students to come down here, and learn to know what a remarkable public library they have here in Cleveland."

\section{A Rare Experience}

Here, indeed, was a situation wholly beyond my experience: a public library where university professors came, and were known by sight to the staff, and a public library which could and did collaborate with a university in building collections of the highest order of scholarship. Since I have been connected with the university, this first impression has been substantiated and deepened a thousand times. To have the pleasure of inhabiting a city where the teachers and students of the city's university are treated as if they too belonged to the "public," and should have their needs considered by the library buyers is a rare one. It would be hard to guess how great the influence of this generous and enlightened policy has been upon the public at large. A library with such treasures to offer becomes a kind of university itself, an ideal place for the cultivation of that art and hobby of amateur scholarship which our country is just beginning to practice.

One reaction of Cleveland's possession of this priceless and unique public institution can certainly be traced: the reaction upon Western r Reserve University. Partly because Cleveland has such a library, Cleveland's university is, to an exceptional degree a "bookish" one, a university where students as well as teachers have come to realize that the art of print- ing, after all, was invented about five centuries ago, and that more can be learned by exploring the contents of printed books than by listening to professors repeat what anyone can read in a textbook. The "lecture system" of college education is an almost perfect illustration of an anachronism, and continues at all, some wag has said, because professors seem not yet to have heard of Gutenberg's invention. Lectures, we are told, probably by the same authority, are merely books so badly written that no publisher would think of printing them.

As a matter of fact, the very word "lecture" originally did not mean a talk at all, but a reading. It carries us back to the old days of higher education in the Middle Ages, when a man became a professor because he was well enough off to own a few of the incredibly expensive books, produced, of course, in longhand. Armed with his book, he proceeded to meet his students, and read to them from the text, occasionally pausing to explain the harder words. This reading was a lecture, in the literal sense of the word. The students, usually too poor to own the vellum on which to write, tried to memorize the text as it was read to them. Obviously, there is no need for lectures today. The teacher's problem is to get books into the hands of his students, and to get his students to read them. With such a public library as Cleveland possesses, this becomes an infinitely easier task than it is in most other cities.

This collaboration and interaction between Western Reserve University and the Cleveland Public Library has been possible because of certain changing concepts of the office of librarian, and the university has had not a little to do with these changes. Papal documents of seven 
or eight centuries ago are full of references to the bibliothecarius, the "librarian" of the Roman church. But the functions of these librarians were very different from those of the librarians of the Cleveland Public Library. It was their business to keep the books and documents of the Roman church safe and secret. They were the dragon-like guardians of inestimably valuable literary treasures. This tradition that it is the chief business of a librarian to keep books away from people obviously has no place in a public library, and yet, incredible as it may seem, that tradition still persists, even in the public libraries of some of America's most enlightened cities.

\section{To Train Library Personnel}

Early in 1903, the late President Charles F. Thwing met Andrew Carnegie on a New York bound train, and the discussion naturally centered around the steel king's announced project to devote a very large proportion of his immense fortune to the building of public libraries. Like many other of America's builders, Carnegie's mind attached itself to the notion of the material housing of libraries. $\mathrm{He}$ had, apparently, given little thought to the question of how so many libraries were to be adequately staffed. To this problem, President Thwing now called his attention, and suggested-oh, these university presidents-that Western Reserve University was admirably located for the purpose of establishing a library school. The story then goes, that when they were on the ferry crossing the North River to Manhattan, Carnegie asked Thwing, "How much?" and the latter replied, rather hastily, "\$IOo,ooo." Carnegie said, "All right," and the two men parted. The president used to say that he had never forgiven himself for not having mentioned five times the sum, since Carnegie never discussed the amount suggested. With this initial endowment, the Western Reserve University School of Library Science opened, in September I904.

To understand how it happened that President Thwing had the foundation of a library school on his mind, we must remember that among the president's fellowClevelanders and admired friends was William Howard Brett, who, since I 884 had been librarian of the Cleveland Public Library. Born in 1846 , in Braceville, Ohio, Brett was, at 14 , librarian of the Warren, Ohio, high school library. $\mathrm{He}$ served as a musician in the Civil War, and studied medicine both in Michigan and at the Cleveland Medical College (later Western Reserve's medical school). His interest in books led him to take a job with Cobb and Andrews, local book dealers. It was from this position, where he made himself hosts of friends, that he was called to become Cleveland's librarian. The library had then only 46,000 books, and was located in the Central High School building.

The three great achievements of Brett's thirty-four years of service were (I) the innovation of opening the shelves to the public, (2) the establishment of branch libraries to serve the people who could not come downtown, and (3) promotion of the $\$ 2,000,000$ bond issue to build the present library building.

\section{Mr. Brett's Influence}

Brett's advanced views as to the meaning of good librarianship, and his twenty years' experience in putting some of them into effect made a deep impression upon President Thwing, and Brett's presence 
in Cleveland was almost certainly the special reason he had in mind for trying to secure a school of library science for Cleveland's university. Carnegie was a great admirer of Brett. He wrote to him in 1914: "Dear Mr. Brett: First, cordial congratulations upon your noble work. You give me the value of the libraries, but if I were going to assess your value to Cleveland, I should have to add a cypher or two. . . Remember what Franklin says: 'The highest worship of God is service to man.' Long life to you who have done so much to make it a heaven." And so, when Western Reserve University opened its School of Library Science in 1904, William Howard Brett became the first dean, and helped to shape its policy and curriculum so that its graduates would be representative of the new type of librarian, whose object was to bring books to the people, not to keep them out of the people's reach.

The list of officers of administration and instruction in the current catalog of the School of Library Science reveals at a glance that almost the whole teaching staff has been or is now connected with the public library. Dean Hirshberg was, for six years, reference librarian. Alice Tyler, dean of the school from 1925 to I929 and now professor emeritus of library science, began her career under $\mathrm{Mr}$. Brett, as catalog librarian. The other professor emeritus, for thirty-four years instructor and professor of library science is Linda Eastman, librarian of the Cleveland Public Library in succession to $\mathrm{Mr}$. Brett. The present librarian, Charles E. Rush, is consultant at the school. May I quote him briefly: "Any newcomer to Cleveland is increasingly amazed to find it so extraordinarily book conscious. Credit for this community's intellectual curiosity and strength must go to the schools, colleges, universities, and libraries. Western Reserve University with its libraries and library school is a fountain head of cultural growth and activity."

One may also note that no less than II heads of the various divisions of the public library are listed as visiting lecturers at the school.

Miss Tyler was succeeded in 1929 as dean by Herbert S. Hirshberg. Dean Hirshberg writes: "The close connection between the school and the Cleveland Public Library was continued by the naming of Miss Eastman as counselor for the school, in which position she advises on all important matters of policy and sits as a regular faculty member in faculty meetings. ..."

Prophets, it is said on the highest authority, are not without honor save in their own country. We of Cleveland perhaps do not fully appreciate that the obvious logic of an association between the university, the library school and the public library has been fully worked out only in Cleveland. There are plenty of great city libraries in the United States; there are other schools of library science (a few of them older) besides that of Western Reserve University, yet only in Cleveland are the university and the community conscious of the fact that the pursuit of similar ends is most efficiently subserved by collaboration. What could be more logical than the collaboration of a public library and a library school? The former offers all its experience in the diffcult practical problems of getting and circulating the right sort of books in the best way. The latter offers all the great traditional lore of books, all the disciplines of the ancient science of bibliog- 
raphy accumulated through thousands of years by the learned. The library can be not only a better public servant by taking the university into its confidence, but the university can turn out better librarians because it can and does treat the library as a great laboratory. As Dean Hirshberg has said: "Because our students get their field work in such an excellent library in the city, they are in demand all over the country." And every one of the I 500 students graduated from the school carries Cleveland's reputation as having a model public library into the cities and towns to which they go. All this is obvious, all this is logical, and yet only here in Cleveland have the community and the university followed the course which logic points out, and brought book-learning and learning books together. 